\title{
First underwater sighting and preliminary behavioural observations of Dugongs (Dugong dugon) in the wild from Indian waters, Andaman Islands
}

\author{
Elrika D' souza ${ }^{1} \&$ Vardhan Patankar² \\ 1,2 Reef Watch Marine Conservation, Priyanka Bldg.,50 St. Paul's Road, Bandra (W), Mumbai, Maharshtra 400050, India \\ Email: ${ }^{1}$ elrikad@ @mail.com, ${ }^{2}$ vardhanpatankar@gmail.com
}

Date of online publication 26 January 2009 ISSN 0974-7907 (online) | 0974-7893 (print)

Editor: Kumaran Sathasivam

\section{Manuscript details: \\ Ms \# 02002 \\ Received 11 June 2008 \\ Final revised received 09 December 2008 \\ Finally accepted 25 December 2008}

Citation: D' souza, E. \& V. Patankar (2009) First underwater sighting and preliminary behavioural observations of Dugongs (Dugong dugon) in the wild from Indian waters, Andaman Islands. Journal of Threatened Taxa 1(1): 4953.

Copyright: (C) Elrika D' souza \& Vardhan Patankar 2009. Creative Commons Attribution 3.0 Unported License. JoTT allows unrestricted use of this article in any medium for nonprofit purposes, reproduction and distribution by providing adequate credit to the authors and the source of publication.

Author Details: ELRIKA D'SOUZA is currently studying ecological aspects of the Dugong and its habitat of the Andaman and Nicobar islands and is also co-researching a study on coral reefs of the Nicobar islands. VARDHAN PATANKAR is currently studying Coral reef recovery in the Nicobar group of Islands and also co-researching a study on the Coconut Crab and Dugong

Author Contributions: The first and second author have jointly contributed to the study and the current paper

Aknowledgements: We greatly acknowledge support received by $\mathrm{HSBC}$ and SWBG Conservation Fund, USA. We thank the Chief Wildlife Warden, Department of Environment and Forests, Port Blair for permitting us to carry out the studies, Dr. A.K. Kumaraguru for his guidance, Nori and Lucan for their inputs and efforts during our field surveys, Mitali Dutt Kakar, Director, Reef Watch Marine Conservation for her continuous support and all at Reef Watch for their consolidated efforts.

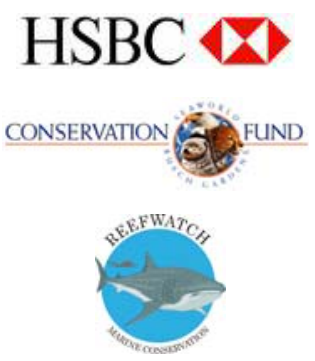

OPEN ACGESS | FREE DOWNLOAD
Abstract: Sighting of Dugongs in Indian waters have become increasingly rare due to their declining numbers. Further, there have been no reports on underwater observations on dugongs in the wild from these waters. During our surveys in the Andaman and Nicobar Islands, we sighted three independent immature sized dugongs. These individuals were sighted at Havelock and Neil Island and Kodiaghat in South Andaman Island. In this paper, we report dugong sightings, present preliminary behavioural observations and emphasise the need to initiate community based conservation along with monitoring of their habitats.

Keywords: Andaman islands, behaviour, Dugongs in Indian waters, sighting

\section{INTRODUCTION}

Dugongs (Dugong dugon) are large marine mammalian grazers of the tropical Indowest-Pacific region where they feed primarily on near-shore sea grasses (Johnstone \& Hudson 1981; Marsh et al. 1982). They are the only extant member of the family Dugongidae in the order Sirenia. Dugongs are bottom feeders and spend little of their time at or near the surface but must surface for 1 to 2 seconds to breathe at regular and frequent intervals (Anderson 1981). They have a large body size (Spain \& Heinsohn 1975) and a hindgut fermenting digestive system (Lanyon \& Marsh 1995). These features, combined with the relatively low nutrient and energy content of their aquatic plant food, suggest that they must spend a high proportion of their time feeding in order to meet their daily food requirements.

The documented geographical range of the dugong extends over the coastal waters of some 37 countries ranging from east Africa, through south and south-east Asia to Australia. This herbivorous mammal, inhabiting the marine environment was once abundant in many parts of its range but numbers have declined and its area of occupancy has decreased in recent times due to exploitation and loss of habitat (Marsh et al. 2001). It is currently listed in the IUCN Red List of Threatened Species as being vulnerable to extinction throughout its global range(IUCN 2007). It is also listed in Appendix I of the Convention on International Trade in Endangered species of Wild Fauna and Flora (CITES), which prohibits all trades in this species or any products derived from it. In India, dugong has been given the highest level of legal protection and is listed under Schedule I of the Indian Wildlife Protection Act, 1972.

Dugongs have been reported from the Gulf of Kutch, off the Saurashtra coast, the Gulf of Mannar and Palk Bay which are part of the Indian main continent (Lal Mohan 1963; Lal Mohan 1980; Mani 1960; Silas 1961; Frazier \& Taej Mundkur 1990; Kumaran 2002). These reports have been based on studies carried out on stranded and incidentally caught dugongs and the only observations on live dugongs from India have been made by Jones (1967a,b) on a pair of dugongs in captivity at Mandapam (Gulf of Mannar). Dugongs have also been reported to be found in the Andaman and Nicobar Islands (Anon 1909; Jones 1980; James 1988; Bhaskar \& Rao 1992; Rao 1990). It has been declared as the State Animal of these Islands. The only comprehensive report on dugongs is by Das and Dey (1999) who estimated the presence of around 40 dugongs based on interviews of fishermen and regular divers that had encountered or sighted dugongs from the Andaman and Nicobar Islands.

To derive appropriate conservation strategies of any endangered wild animal, an understanding of its behaviour in the wild is important (Buchholz 2007; Caro 1999). Dugong sightings around the Andaman and Nicobar islands are rare due to their low numbers (Das 1999) and also because it is difficult to sight and make behavioral observations on aquatic animals that generally live in turbid water and only come to the 


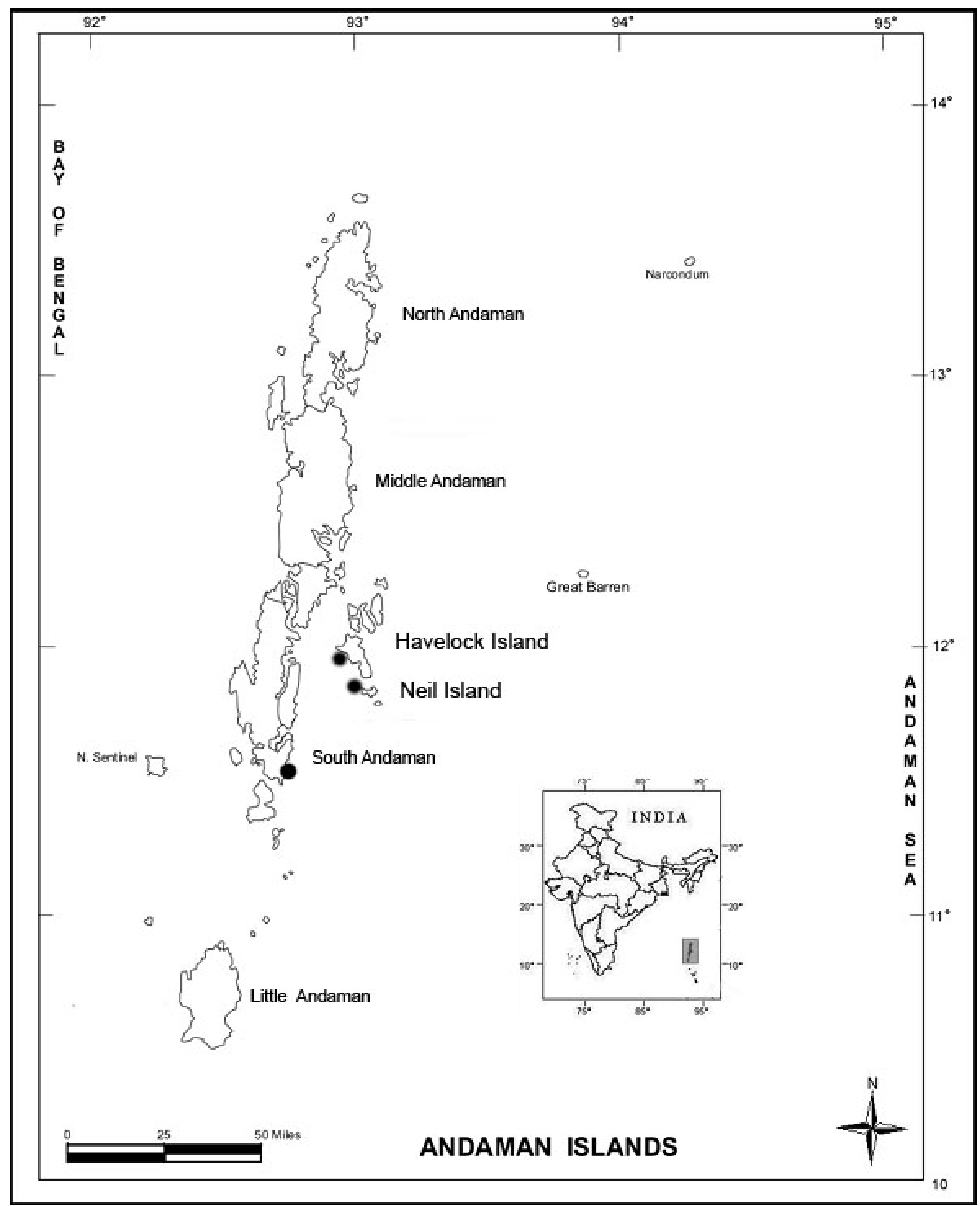

Figure 1. Locations of Dugong sightings 


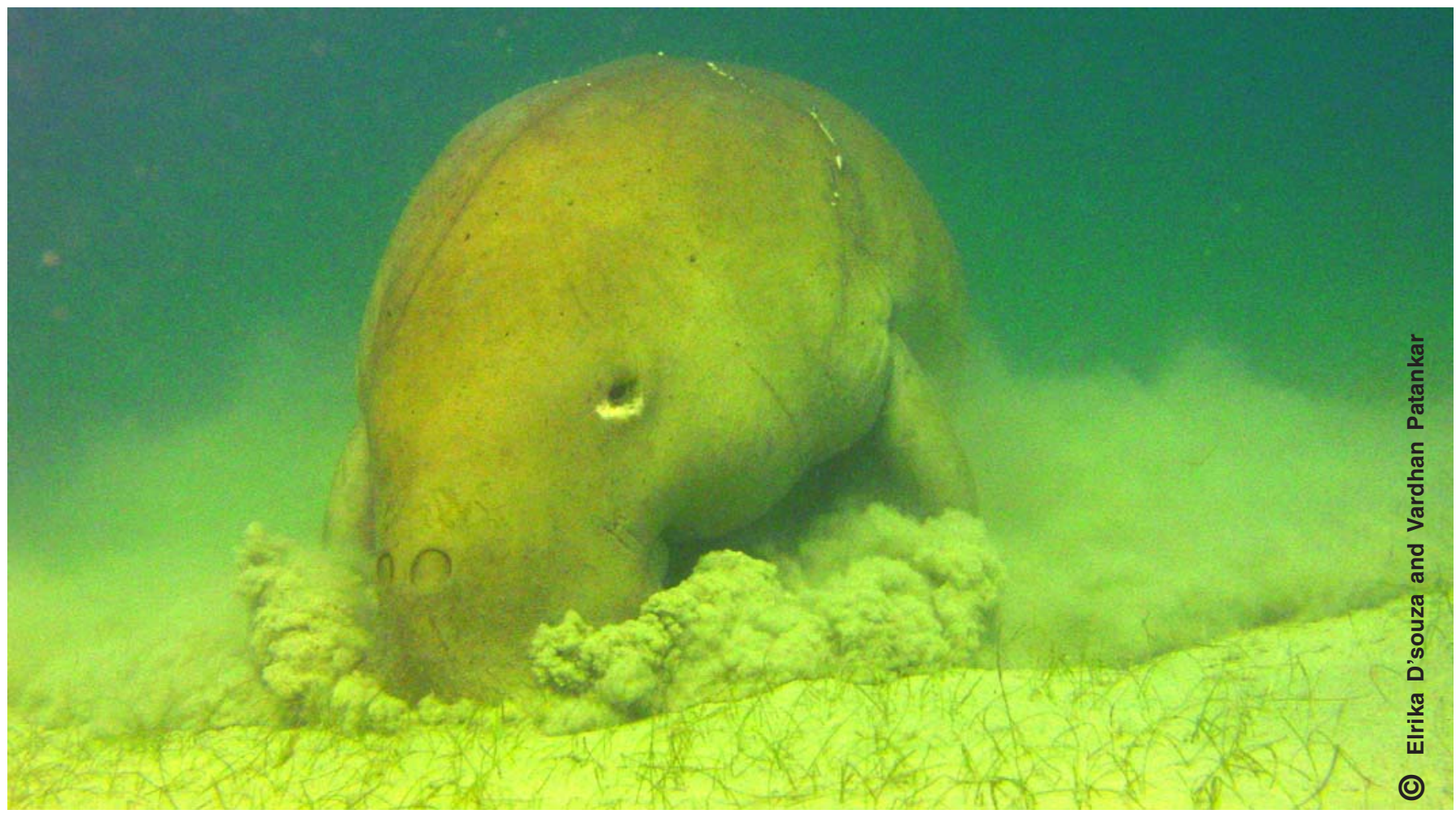

Image 1. Dugong feeding on seagrass

surface briefly to breathe (Chilvers et al. 2004). To date, there have been no reports on dugong behaviour in the wild from Indian waters and studies on dugong diving and feeding behaviours carried out in Australia have been based on visual observations from boats or shoreline vantage points (Anderson \& Birtles 1978; Reynolds 1981; Anderson 1982, 1998; Marsh \& Rathbun 1990; Whiting 2002) and through satellite tagging (Chilvers et al. 2004). It is expected that the behaviour may vary, given the climatic, environmental and geographical differences. In this context, here we report the first underwater sightings and preliminary behavioural observations of dugongs in the wild from Indian waters, Andaman Islands.

\section{Materials and Methods}

The Andaman and Nicobar Islands are one of the biodiversity hotspots in the world (Myers et al. 2000), which are located in the south-eastern part of the Bay of Bengal, between $06^{\circ} 45^{\prime}-13^{\circ} 411^{\prime} \mathrm{N} \& 92^{\circ} 12^{\prime}-93^{\circ} 57^{\prime} \mathrm{E}$. The Andaman group consists of 4 large islands, North, Middle, Baratang and South Andaman Islands forming a super island of over 5,000 $\mathrm{km}^{2}$ in area, surrounded by archipelagoes and isolated islands (Davidar, 1994). The Nicobar group of islands is separated from the Andaman group by the 10 degree channel. This group comprise of about 23 islands.

The study was carried out between February 2007 and March 2008. Surveys were carried out around Interview, North Reef, Neil, Havelock, Chidiatapu, Burmanalla, Kodiaghat, Kamorta, Nancowry and Trinket. These areas were selected based on earlier documented records of seagrass beds, dugong occurrence and informal discussions with local authorities and islanders. Survey sites were accessed in local dinghies or from the shore by snorkeling and SCUBA diving. Information on the extent of seagrass beds and species composition was gathered. GPS coordinates of sites that showed dugong feeding trails were recorded and these sites were monitored for the possibility of sighting dugongs. Upon sighting of the animal, underwater observations were made by maintaining a $2 \mathrm{~m}$ distance from the individual. The sighted individual's size, sex, scars and body parts were observed and photo-documented. The period of time the animal spent at the surface (surface time) and the time spent submerged between successive surfacing (submergence time) were recorded. The behaviour was classified into five categories, feeding (movement of muzzles over seagrass resulting in ingestion of food), idling (seemingly undirected activity on a small area) (Anderson 1981), resting (stillness with absence of any kind of movement), communicating (emission of sounds in the form of squeaks and barks) and observer directed behaviour.

\section{Results}

Three independent immature sized dugongs were sighted. The first dugong was sighted on the south eastern side of Havelock Island $\left(11^{\circ} 56^{\prime}-11^{\circ} 59^{\prime} \mathrm{N} \& 92^{\circ} 56^{\prime}-92^{\circ} 59^{\prime} \mathrm{E}\right)$ and behavioural observations were made for $47 \mathrm{~h}$. The individual was approximately $2 \mathrm{~m}$ long, with distinct scars on its body; an $\mathrm{X}$-mark on its head, a line running back from the right pectoral, roughly circular marks above the left pectoral and on the underside of the base of the tail and 2 notches on the tail. It was observed feeding on seagrass (Halodule sp. and Halophila sp.) at an average depth of $6 \mathrm{~m}$ and at a maximum distance of $100 \mathrm{~m}$ from the shore. It spent a mean period of $9.4 \pm 0.7 \mathrm{~h}$, $\mathrm{n}=15$ a day feeding in an area of $0.1 \mathrm{~km}^{2}$. The density of seagrass was sparse and the lengths of the shoots were less than $100 \mathrm{~mm}$. When feeding on these low growing sea grasses, the dugong dug into the bottom with its muzzle, extracting and consuming leaves, stems and interconnecting rhizomes. In this 


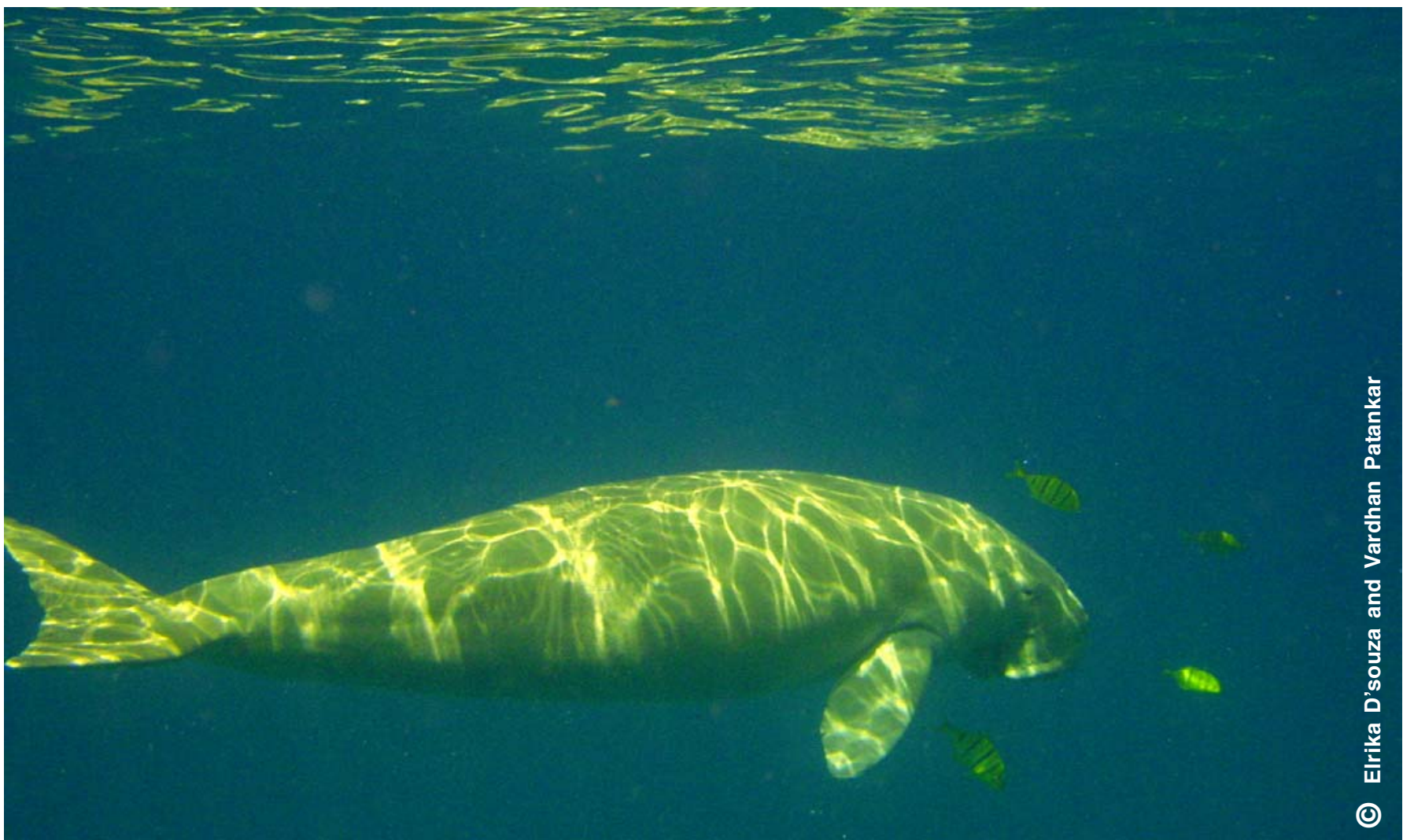

Image 2. Dugong idling

process, it reworked the upper $20-30 \mathrm{~mm}$ of substrate raising clouds of fine sediment and leaving behind distinct long, serpentine feeding trails (Image 1). It surfaced at mean intervals of $231.8 \pm 13.5 \mathrm{~s}, \mathrm{n}=22$ (submergence time) to breathe at an angle of $45^{\circ}$ exhaling once it reached the surface. The breathing pattern comprised of 2 short breaths at mean intervals of $31.1 \pm 6.0 \mathrm{~s}, \mathrm{n}=22$ followed by a longer third breath. The mean total surface time was $59.2 \pm 6.0 \mathrm{~s}, \mathrm{n}=22$. This was followed by an arching of the body and a forward roll which raised the mid-dorsal region and then the tail above the surface giving a downward thrust. The descent was generally at a steeper angle and on reaching the bottom; the dugong supported itself on its pectorals without the body actually touching the sea bed. The pectorals were also used for locomotion on the bottom.

The second dugong was sighted around Neil Island $\left(11^{\circ} 49^{\prime}-\right.$ $11^{\circ} 50^{\prime} \mathrm{N} \& 93^{\circ} \mathrm{OO}-93^{\circ} \mathrm{O} 2^{\prime} \mathrm{E}$ ) and behavioural observations were made for $54 \mathrm{~h}$. It was approximately $2.5 \mathrm{~m}$ long, had a distinct crescent scar on the left side above the pectoral, a notch on the inner side of the left and right pectoral and the left side of the tail and a scar running along the lower half of the trunk. It was observed feeding on Halodule sp. and Halophila sp. at an average depth of $9 \mathrm{~m}$, and at a maximum distance of $100 \mathrm{~m}$ from the shore during the neap tide. While feeding, it surfaced at mean intervals of $268.4 \pm 14.6 \mathrm{~s}, \mathrm{n}=41$ and spent a mean period of $2.9 \pm 0.8 \mathrm{~h}, \mathrm{n}=36$ a day feeding. During the spring tide it was observed idling and resting at this site (Image 2). While idling, it swam at an average depth of $3 \mathrm{~m}$ and up-to a distance of $300 \mathrm{~m}$ from the shore. It moved with the help of its tail and surfaced at mean intervals of $326.1 \pm 11.8 \mathrm{~s}, \mathrm{n}=29$ and spent a mean period of $4.1 \pm 0.8 \mathrm{~h}, \mathrm{n}=14$ a day idling. While resting, it remained close to the surface without any movement and closed its eyes. It was observed resting for a mean period of $1.2 \pm 0.3 \mathrm{~h}, \mathrm{n}=4$. While idling and resting, it just submerged while moving forward without arching and rolling. It was observed communicating in the form of long squeaks. Both the dugongs sometimes had 1-2 remoras attached posteriorly and ventrally to their bodies and were always preceded by juvenile pilot fish. The third dugong was sighted at Kodiaghat $\left(11^{\circ} 31^{\prime} 49.25^{\prime \prime} \mathrm{N} \& 92^{\circ} 43^{\prime} 36.68^{\prime \prime} \mathrm{E}\right)$ in south Andaman and was observed for a brief period of $590 \mathrm{~s}$ at a depth of $7 \mathrm{~m}$. It was approximately $3 \mathrm{~m}$ long and it showed observer directed behaviour. It curiously approached us and stopped at a distance of $2 \mathrm{~m}$ from us. It then circled us twice surfacing to breathe between each circling. It followed the similar breathing pattern of two short breaths and a third long breath. All three individuals were identified as males and confirmation of the sex was done by an observation of the genital parts.

\section{Discussion}

The only observations on Dugong behaviour in India have been made by Jones (1967a). These Dugongs were in captivity at the Mandapam camp in a tank where the water was barely $1 \mathrm{~m}$ deep and therefore freedom of movement was restricted. They could only make horizontal movements and were unable to assume a vertical position. Also, they had become so tame that they had started accepting food from the hands of the feeder (Jones 1967a). Therefore, our observations differ from that of Jones as the observations on the Dugongs were made in their natural habitat and not within a controlled environment. These observations made on dugongs from Indian waters were found to be similar to those made in Australian waters i.e. Dugongs were found to spend a mean time of $4.2 \mathrm{~min} \pm 1 \mathrm{~s}$ at mean depths of $7.2 \pm 0.1 \mathrm{~m}$ (Chilvers et al. 2004). However, 
since these observations were limited to 3 individuals, generalisations and conclusive inferences can only be made after studies are extended to a larger population.

Dugongs are very individualistic in their behaviour and movements (Marsh \& Rathbun 1990; Marsh et al. 2002) and hence understanding the behaviour of individuals and herds in relation to daily cycles, tidal state, environmental variables can be taken into consideration for the conservation and management of the species in its local area of occupancy. Another significant observation was that the individuals exhibited a non-aggressive and exploratory behaviour which could render them vulnerable to hunting. Therefore we recommend local community-based conservation initiative programmes along with regular monitoring of Dugong habitats. Low-cost studies such as this can reveal important information on the unexplored aspects of the behavioural patterns of the dugong that would be important for formulating conservation strategies in developing countries like India where Dugong populations are relatively small.

\section{References}

Anderson, P.K. (1981). The behaviour of the Dugong (Dugong dugon) in relation to Conservation and Management. Bulletin of Marine Science $31(3): 640-647$.

Anderson, P.K. (1982). Studies of dugongs at Shark Bay, Western Australia: II. Surface and subsurface observations. Australian Wildlife Research 9: 85-99

Anderson, P.K. (1998). Shark Bay dugongs (Dugong dugon) in summer: II. Foragers in a Halodule-dominated community. Mammalia 62: 409425 .

Anderson, P.K. \& A. Birtles (1978). Behaviour and ecology of the dugong Dugong dugon (Sirenia): observations in Shoalwater and Clevland Bays, Quensland. Australian Wildlife Research 5: 1-23.

Anon (1909). The Imperial Gazetteer of India. The Indian Empire. Vol 1. Descriptive. Clarendon, Oxford. xxxi+568pp.

Bhaskar, S. \& G.C. Rao (1992). Present status of some endangered animals in Nicobar Islands. Journal Andaman Science Association 8(2): 181-186.

Buchholz, R. (2007). Behavioural biology: an effective and relevant conservation tool. Trends in Ecology and Evolution 22(8): 401-407.

Caro, T. (1999). The behaviour-conservation interface. Trends in Ecology and Evolution 14(9): 366-369.

Chilvers, B.L., S. Delean, N.J. Gales, D.K. Holley, I.R. Lawler, H. Marsh \& A.R. Preen (2004). Diving behaviour of dugongs, Dugong dugon. Journal of Experimental Marine Biology and Ecology 304: 203-224.

Das, H.S. \& Dey, S.C. (1999). Observations on the Dugong, Dugong dugon (Müller), in the Andaman and Nicobar Islands, India. Journal, Bombay Natural History Society 96(2): 195-198.

Davidar, P., S. Devy, T.R.K. Yoganand \& T. Ganesh (1994). Reserve size and implications for the conservation of biodiversity in the Andaman Islands. Proceedings of the IUFRO Symposium 287-301.

Frazier, J.G. \& Taej Mundkur (1990). Dugong, Dugong dugon (Müller) in the Gulf of Kutch, Gujarat. Journal Bombay Natural History Society 87: 368-379.

IUCN (2007). 2007 IUCN Red List of Threatened Species. $<$ www.iucnredlist.org $>$. Downloaded on 08 May 2008
James, D.B. (1988). Some observations and remarks in the Endangered Marine Animals of Andaman and Nicobar Islands. Proceedings of the Symposium on Endangered Marine Animals and Marine Parks 337-340.

Johnstone, I. \& B.E.T. Hudson (1981). The dugong diet: mouth sample analysis. Bulletin of Marine Sciences 31: 681-690.

Jones, S. (1967a). The Dugong dugon (Müller), its present status in the seas around India with observations on its behaviour in captivity. International Zoological Yearbook 7: 215-220.

Jones, S. (1967b). On a pair of captive dugongs Dugong dugon (Erxleben). Loris 11(2): 83-86.

Jones, S. (1980). The dugong or the so-called mermaid, Dugong dugon (Müller) of the Indo-Sri Lankan waters - problems of research and conservation. Spolea Zeylanica (Colombo Museum Centenary Volume) 35(I\&II): 223-260.

Kumaran, P.L. (2002). Marine Mammals research in India-a review and critique of the methods. Current Science 83(10): 1210-1220.

Lal Mohan, R.S. (1963). On the occurrence of Dugong dugon (Müller) of the Gulf of Kutch. Journal of the Marine Biological Association India $5(1): 152$.

Lal Mohan, R.S. (1980). Some observations on the Sea-cow Dugong dugon (Müller) in the Gulf of Mannar and Palk Bay during 19711975. Journal of the Marine Biological Association India 18(2): $391-$ 396.

Lanyon, J.M., Marsh, H. (1995). Digesta passage times in the Dugong. Australian Journal of Zoology 43: 119-127.

Mani, S.B. (1960). Occurrence of the Sea-cow Halicore dugong (Erxl) off Saurashtra coast. Journal of the Bombay Natural History Society 56: 216-217.

Marsh, H., P.W. Chanells, G.E. Heinsohn \& J. Morrissey (1982). Analysis of stomach contents of dugongs from Queensland. Australian Wildlife Research. 9: 55-67.

Marsh, H., C. Eros, H. Penrose \& J. Hugues (2002). Dugong Status Report and Action Plans for Countries and Territories. UNEP Early Warning and Assessment Report Series 1. 162pp

Marsh, H. \& G.B. Rathbun (1990). Development and application of conventional and satellite radio tracking techniques for studying dugong movements and habitat use. Australian Wildlife Research 17: 83-100.

Myers, N., R.A. Mittermeier, C.G. Mittermeier, G.A.B. da Fonsec \& J. Kent (2000). Biodiversity hotspots for conservation priorities. Nature 403: 853-858

Preen, A.R. (1995). Impacts of dugong foraging on seagrass habitats: observational and experimental evidence for cultivation grazing. Marine Ecology Progress Series 124: 201-213.

Rao, G.C. (1990). Present status of the sea cow, Dugong dugon (Müller) in Bay Islands. Journal Andaman Science Association 6(2): 181-186.

Reynolds III, J.E. (1981). Behaviour patterns in the West Indian manatee, with emphasis on feeding and diving (Florida). Science 44: 232-242.

Silas, E.G. (1961). Occurrence of the Sea-cow Halicore dugong (Erxl) off Saurashtra coast. Journal of the Bombay Natural History Society 58: 263-266.

Spain, A.V. \& Heinsohn, G.E. (1975). Size and weight allometry in a North Queensland population of Dugong dugon (Müller) (Mammalia: Sirenia). Australian Journal of Zoology 3: 159-68.

Whiting, S.D. (2002). Dive times for foraging dugongs in the Northern Territory. Australian Mammalogy 23: 167-168. 